\title{
Comparison of Okadaic Acid Profiles in Mussels and Oysters Collected in Mediterranean Lagoon, Tunisia
}

\author{
Imène Kacem (Corresponding author) \\ Laboratoire de Chimie Organique, Institut National Agronomique de Tunisie \\ 43, Avenue Charles Nicolle - 1082 Cité Mahrajène - Tunis, Tunisie \\ Tel: 216-2277-4189Ｅ-mail: imen.kacem@yahoo.fr
}

Noureddine Bouaïcha

Noureddine Bouaicha: Laboratoire Ecologie, Systématique et Evolution UMR 8079

Université Paris-Sud 11, Rue J.B. Clément, 92296 Chatenay-Malabry, France

Béchir Hajjem

Institut National Agronomique de Tunisie- Tunis, Tunisie

Université Paris-Sud 11, France

\&

Laboratoire de Chimie Organique, Institut National Agronomique de Tunisie

43, Avenue Charles Nicolle - 1082 Cité Mahrajène - Tunis, Tunisie

\begin{abstract}
Produced by marine microalgae, okadaic acid is a highly selective inhibitor of protein phosphatases, as well as being a potent tumour promoter. In this paper, we report on a comparison of the toxin profiles in mussels and oysters by protein phosphatase inhibition assay (PP2A) and liquid chromatography with fluorescence detection (HPLC). Samples of Mytilus galloprovincialis and Crassostrea gigas were harvested from Bizerta lagoon during 8 months. All of the mussel samples (November excepted) were found to be contaminated with OA to levels of about $10.2 \mathrm{eq} \mu \mathrm{g} / 100 \mathrm{~g}$ wet weight (PP2A assay). However, OA-group in oysters were detected only from April to July to a maximum limit of $1.45 \mathrm{eq} \mu \mathrm{g} / 100 \mathrm{~g}$ wet weight (PP2A assay). Overall, levels were 10-70 times greater in mussels. The results showed that OA-group toxins appeared to be reduced at a faster rate in oysters $\left(\mathrm{t}_{1 / 2}=9\right.$ days $)$ compared with mussels $\left(\mathrm{t}_{1 / 2}=18\right.$ days $)$.
\end{abstract}

Keywords: Okadaic acid, Mytilus galloprovincialis, Crassostrea gigas, Mediterranean Lagoon

\section{Introduction}

Episodes of poisoning occasionally occur when toxic phytoplankton are filtered from the water as food by shellfish (mussels, oysters, clams) which then accumulate the algal toxins to levels which can be lethal to humans.

Phycotoxins derived from the harmful algal blooms (HABs) have caused world-wide public concern in the last several decades due to their potential threat to the health of humans. Diarrhetic shellfish poison (DSP) is associated with polycyclic ether toxins: okadaic acid, dinophysistoxins, and pectenotoxins (Bowden, 2006). The most important toxins involved in DSP are represented by the okadaic acid (OA) and dinophysistoxins (DTX1 and DTX2) for their diarrhoeogenic effect and for their worldwide occurrence (Yasumoto and Murata, 1993).

Although no serious acute toxicities of Okadaic acid were reported, the chronic effects of the toxins, such as tumor promotion resulting from the inhibition of protein phosphatase (Suganuma et al. 1988), caused much concern. In Tunisia, blue mussels collected from the Bizerte lagoon are found to be contaminated for the first time with OA produced by dinoflagellates of genera Dinophysis and accumulated inside shellfish in waters containing these algae (Kacem et al., 2009). 
One of the most promising methods that appeared recently for analysis of DSP toxins was the protein phosphatase inhibition assay based on the inhibition of the enzyme activity by OA and DTXs. PP1 and PP2A were the major forms of protein phosphatase, which catalyzed the phosphorylation on serine and threonine residues (Aifeng et al., 2006).

The aim of this study was the comparison of oyster (Crassostrea gigas) and blue mussel (Mytilus galloprovincialis) contamination by OA-like toxins during the investigation period from April through November 2006. The PP2A inhibition assay using p-nitrophenylphosphate (p-NPP) as substrate, and HPLC methods using ADAM as fluorimetric derivatizing agents were used to quantify the diarrheic OA-like toxins in shellfish.

\section{Materials and methods}

\subsection{Chemicals and reagents}

Buffers and general reagents were from Sigma-Aldrich (Saint-Quentin Fallavier, France). All solvents (dichloromethane, chloroform, n-hexane, acetonitrile and methanol) were purchased from Baker (Noisy Le Sec,

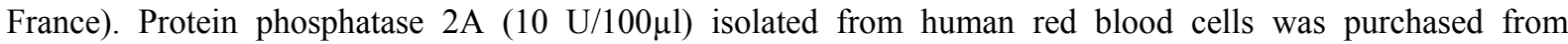
Euromedex (Mundolsheim, France). Okadaic acid standard (CAS no: 155751-72-7) and the 9-anthryldiazomethan (ADAM) reagent, were purchased from Sigma-Aldrich (Saint-Quentin Fallavier, France).

\subsection{Study site and sampling}

The study was carried out February 2006 through October 2006 on a mussel farm located in the Bizerta lagoon $\left(\left(37^{\circ} 8^{\prime}-37^{\circ} 14^{\prime} \mathrm{N}, 9^{\circ} 48^{\prime}-9^{\circ} 56^{\prime} \mathrm{E}\right)\right.$, a semi enclosed area with a surface area of $150 \mathrm{~km}^{2}$ and a mean depth of $8 \mathrm{~m}$. (fig 1). Exchanges with the Mediterranean Sea occur through the $7 \mathrm{~km}$ long channel that has a depth of $12 \mathrm{~m}$. The area covered by the farm is $650 \mathrm{~m}^{2}$ and the average bottom depth is $5 \mathrm{~m}$. The mussels were cultivated using a suspension-culture technique, in which the mussel larvae settle on ropes hanging down from long, horizontally anchored lines. Phytoplankton samples were harvested twice a month (March-November 2006) from the water surface of the lagoon and were fixed with formaldehyde at $1 \%$. The dinoflagellate species were identified using universally accepted taxonomic keys based especially on the morphology and the valve description of the cells (Sournia, 1986; Faust, 1996; 1999). On the other hand, $2 \mathrm{~kg}$ of mussels (Mytilus galloprovincialis) and oysters (crassostrea gigas) were collected monthly (April-November) at the same site from the area of Bizerte's lagoon at $3 \mathrm{~m}$ depth and stored at $-20^{\circ} \mathrm{C}$ prior to extraction.

\subsection{Phycotoxins extraction procedure}

The whole flesh mussel and oyster tissue was removed from the shell and rinsed with freshwater and then drained for $5 \mathrm{~min}$ in a sieve to remove salt water and sediment. An aliquot of $100 \mathrm{~g}$ of flesh mussel/oyster tissue from each sample was homogenized and extracted in triplicate in a blender with $100 \mathrm{ml}$ of $80 \%$ aqueous methanol. Each extract was then clarified by filtration through a glass microfiber filter (GF/C, Whatmann). The process of homogenisation, extraction and filtration was repeated two additional times. For each sample, the three filtrates generated were pooled, partitioned with n-hexane and then toxins were extracted using dichloromethane. Each dichloromethane extract was then evaporated to dryness and the residue was reconstituted in $10 \mathrm{ml}$ of methanol and stored at $-20^{\circ} \mathrm{C}$. All crude methanolic extracts were then analysed with PP2A inhibition assays and HPLC-fluroescence detection.

\subsection{Protein phosphatse inhibition assay}

Protein Phosphatase 2A assays were used according to Tubaro et al. (1996) with minor modifications. A series of OA standard solutions, 100, 150, 200, 300, 400, 500, 700, 800, 1000, 1500 and $2000 \mathrm{pg} \mathrm{ml}^{-1}$ was prepared in methanol. The standard solutions were used to prepare a calibration curve in PP2A protein phosphatase inhibition assay at the range from 100 to $2000 \mathrm{pg} \mathrm{ml}^{-1}$. Triplicate standard solutions were used during the assay. The assay was carried out in 96-well plates with a microplate reader (Bio-Tek Instruments, ELX800G)). The reaction system contained $40 \mathrm{mM}$ Tris $\mathrm{HCl}$ buffer, $34 \mathrm{mM} \mathrm{MgCl}_{2}, 4 \mathrm{mM}$ EDTA, $4 \mathrm{mM}$ Dithiothreitol, $\mathrm{pH}$ 8.3. The PP2A was diluted in the same buffer, and supplemented with $0.5 \mathrm{mg} \mathrm{mL}^{-1}$ bovine serum albumin (BSA). After incubating at $37^{\circ} \mathrm{C}$ for $5 \mathrm{~min}, 50 \mu \mathrm{L}$ of substrate were added. Briefly, the PP2A activity was determined by measuring coloration associated with the formation at $37^{\circ} \mathrm{C}$ of $p$-NP from the substrate $p$-NPP. The rate of para-nitrophenol $(p-\mathrm{NP})$ production was measured after $1 \mathrm{~h}$ at $405 \mathrm{~nm}$. All assays were conducted in triplicate. The activity of the enzyme was determined by linear regression of the reaction curve, and the relative activity of the enzyme after inhibition by OA was interpreted as the ratio of the enzyme activity treated with OA standard to that of the control, which use methanol solution instead of OA standard in the reaction system. The blank was also used, where no enzyme was added, to get rid of the background. 
The 'toxin equivalent' concentration in each extract (OA equivalent/100 g fresh mussel/oyster weight) was determined from the standard graph of the inhibition of PP2A by pure OA (Sigma) with an $\mathrm{IC}_{50}$ of about $320 \mathrm{pg}$ $\mathrm{mL}^{-1}$. The lack of specificity of the protein phosphatase inhibition assay for okadaic acid phycotoxins group means that additional confirmatory analytical methods have to be employed for the specific analysis of these phycotoxins. However, this assay is still a useful screening method, which is easy to use and provides useful toxicological information.

\subsection{Derivatization of OA-like toxins with ADAM and liquid chromatography-fluorescence detection method of okadaic acid}

The derivatization of okadaic acid standard and mussel samples, was carried out according to Lee et al. (1987). Briefly, an aliquot of dichloromethane mussel extract residues or okadaic acid standard (0-80 ng) was treated with $100 \mu \mathrm{l}$ of a freshly prepared solution of $0.1 \%$ ADAM (in methanol). After $1 \mathrm{~h}$ at $25^{\circ} \mathrm{C}$ in the dark, the sample was evaporated to dryness and the residue was diluted in $500 \mu \mathrm{l}$ of $\mathrm{n}$-hexane/chloroform, 1:1 (v/v) and then transferred into $500 \mathrm{mg}$ Silica gel Sep Pak cartridge (Baker, Noisy Le Sec, France). The system was washed successively with $5 \mathrm{ml}$ of $\mathrm{n}$-hexane/chloroform, $1: 1(\mathrm{v} / \mathrm{v})$ and $5 \mathrm{ml}$ of chloroform. Finally, the toxin derivatives were eluted with $5 \mathrm{ml}$ of chloroform/methanol, 9.5:0.5 (v/v).

The last fraction was evaporated to dryness, dissolved in $200 \mu \mathrm{l}$ of methanol and then $10 \mu \mathrm{l}$ was injected and analyzed by HPLC with fluorescent on line detection. Chromatographic separation of toxin derivatives was carried out in a Jasco HPLC multisolvent delivery system, equipped with a pump (PU-1580), an automatic sampler (AS-1555-10), and a scanning fluorescence detector (FP-1520). The separation of toxin derivatives was carried out on a reversed-phase $\mathrm{C} 18$ column $(150 \times 4.6 \mathrm{~mm} ; 3.5 \mu \mathrm{m}$; Kromasil $)$ kept at $35{ }^{\circ} \mathrm{C}$ using a mobile phase consisting of acetonitrile/methanol/water $(70 / 20 / 10, \mathrm{v} / \mathrm{v})$ in an isocratric condition at a flow rate of 1.2 $\mathrm{ml} / \mathrm{min}$. The excitation and emission wavelengths were set at $365 \mathrm{~nm}$ and $415 \mathrm{~nm}$, respectively. Peaks in the resulting chromatograms were identified by comparison with the retention time of okadaic acid analytical standard. The okadaic acid concentration in each flesh mussel tissue was estimated from a calibration curve of okadaic acid standard (0-80 ng).

\section{Results}

\subsection{Identification of dinoflagellates}

The most important, potentially harmful micro-algae recorded in the study area (the Bizerte Lagoon) can be grouped into two categories of DSP producers: pelagic dinoflagellate species such as Dinophysis caudata and D. sacculus; and benthic species, such as Prorocentrum lima.

The benthic species, $P$. lima was observed in March and August 2006 but at low cell densities $\left(<20\right.$ cells L $\left.{ }^{-1}\right)$ in the seawater samples. While, the planktonic species, Dinophysis caudata was observed only in September 2006 at low cell density $\left(10\right.$ cells $\left.\mathrm{L}^{-1}\right)$. The species $D$. sacculus was most frequently observed at low cell density $(<50$ cells $\left.\mathrm{L}^{-1}\right)$ in February, August and September 2006, and at middle cell density (180 cells $\left.\mathrm{L}^{-1}\right)$ in March 2006, reaching a high cell density in April $2006\left(420\right.$ cells L $\left.^{-1}\right)$.

3.2 Preparation of the calibration curve and DSP toxicity assay of the shellfish samples using PP2A protein phosphatase inhibition assay

An S-shaped curve of relative enzyme activity against the logarithm of OA concentration was obtained (shown in Fig. 2), using a series of OA standard solutions. A negative linear correlation (slope $=-1.916 ; R^{2}=0.9723$ ) between the relative enzyme activity and OA concentration could be found when OA concentration was in the range of 300-900 $\mathrm{pg} \mathrm{ml}^{-1}$, corresponding to the relative enzyme activity ranging from $66.0 \%$ to $20.0 \%$. The range of relative enzyme activity was critical for accurate analysis of DSP toxicity, and only results that fell in this range were acceptable for the calculation of toxicity. When OA concentration was higher than $900 \mathrm{pg} \mathrm{ml}^{-1} \mathrm{or}$ lower than $300 \mathrm{pg} \mathrm{ml}^{-1}$, the analytical result would not be very accurate because of the decreased sensitivity or increased discrepancy. This calibration curve was used to analyze the toxicity of oyster and mussel samples.

\subsection{Monthly fluctuation of Okadaic acid levels in mussels and oysters}

The OA-like toxins in shellfish samples were analyzed with the PP2A inhibition assay using p-nitrophenylphosphate (p-NPP) as substrate, and with HPLC using ADAM as fluorimetric derivatizing agents, respectively. The seasonal fluctuations of the OA-like toxins in mussel flesh tissue, estimated from a calibration curve of okadaic acid standard (0-80 ng) (Fig.3), are shown in Figure 4.

Measurable toxin levels were detected in all the samples examined except in August 2006. During the eight month monitoring program from April to November 2006, the OA equivalent concentrations calculated using the 
PP2A assay ranged from 0.09 to $10.2 \mu \mathrm{g} / 100 \mathrm{~g}$ wet weight mussel tissue and from 0.02 to $1.45 \mu \mathrm{g} / 100 \mathrm{~g}$ wet weight oyster tissue, except in August, September, October and November 2006 when no OA was detected in oysters (Fig5).

The peak value of Okadaic acid detected in mussels was observed on 18 May 2006, with a respective concentration $10.20 \pm 1.05 \mu \mathrm{g}$ OA equivalents $/ 100 \mathrm{~g}$ wet weight (PP2A assay) and $8.23 \mu \mathrm{g} / 100 \mathrm{~g}$ wet weight using HPLC (Fig.5).

Mussel and oyster extracts analysed by the PP2A inhibition assay presented differences, in fact toxicity in the mussels was $2.97 \mu \mathrm{g} / 100 \mathrm{~g}$ wet weight on 26 April 2006 and increased to $5.7 \mu \mathrm{g} / 100 \mathrm{~g}$ wet weight in June with a peak observed on 18 May $2006(10.20 \mu \mathrm{g} / 100 \mathrm{~g}$ wet weight). However the peak value of Okadaic acid detected in oysters was observed only on 26 April 2006 with a concentration of $1.45 \pm 0.15 \mu \mathrm{g}$ OA equivalents $/ 100 \mathrm{~g}$ wet weight and the toxicity period was observed for a short period from April $(0.67 \mu \mathrm{g} / 100 \mathrm{~g}$ wet weight $)$ to June $2006(0.32 \mu \mathrm{g} / 100)$.

\section{Discussion}

The most important toxins involved in DSP are represented by the okadaic acid (OA) group for their diarrhoeogenic effect and for their world-wide occurrence (Yasumoto and Murata, 1993). During this study (April-November 2006), we observed the presence, in Bizerte Lagoon, of three potentially toxic dinoflagellate species such as Dinophysis caudata, D. sacculus and Prorocentrum lima. The dominant species was Dinophysis sacculus which appeared in March 2006 (180 cells L $\left.{ }^{-1}\right)$, reaching a higher density in April $2006\left(420\right.$ cell L $\left.^{-1}\right)$. Therefore, the OA detected in the mussel samples from this Lagoon was produced by D. sacculus, which is known in the literature as DSP toxins producers (Camacho et al., 2007). Indeed, Dinophysis species have been linked to DSP occurrences along the Mediterranean and Atlantic European coasts (Sampayo et al., 1990; Marasovic et al., 1998).

In the present study, it was confirmed by HPLC, that mussels contained okadaic acid, which dominated from April until the end of June 2006 with a maximum concentration of $8.23 \mu \mathrm{g} / 100 \mathrm{~g}$ of OA found in May 2006 . Generally, there was good correlation obtained between OA determined by the PP2A method and the HPLC-ADAM method (Mountfort et al., 2001). In this study, the concentrations of OA for some mussel samples were underestimated by the HPLC-ADAM method compared to the PP2A assay as indicated in Figure 5. This may be due to losses in yield at critical stages of sample preparation for HPLC during the derivatization and the extraction protocol. It is also likely that the PP2A method overestimated the toxin concentration due to the ability of this assay to detect a broad range of OA homologues (dinophysistoxins) present at low concentrations in the mussel samples. The comparison of okadaic acid profiles in mussels and oysters collected in the Lagoon of Bizerte showed that the proportion of diarrhoeic toxin in mussels was approximately twice as much as those in the oysters, analysed by PP2A assay. Although the Lindegarth et al. (2009) study concerned the Blue Mussel, Mytilus edulis and European Flat Oyster, Ostrea edulis, the results reported are equivalent to those found in this study based on the Blue Mussel, Mytilus galloprovincialis and Japanese Oyster, Crassostrea gigas. In fact, Lindegarth et al. (2009) showed that Mytilus edulis rapidly accumulated OA-group toxins to levels about 10 times above the regulation limit $\left(160 \mu \mathrm{g} \mathrm{OA} \mathrm{kg}{ }^{-1}\right.$ mussel $)$ whereas concentrations never reached this limit in Ostrea edulis during the field exposure. Based on this, C. gigas may be regarded as a low-risk species for diarrhetic shellfish toxins (DST), contamination compared to M. galloprovincialis.

Furthermore, we observed that after May 2006 OA levels of mussel samples in the Bizerte Lagoon began a steady decline, and by July 2006 concentration decreased to $8 \%$ of initial value. On the other hand, OA levels of oyster samples, at the same site, began a steady decline after May in which a higher level of OA was observed and by June and July 2006, concentration decreased respectively to $22.2 \%$ and $1.6 \%$ of initial value. Faster elimination of OA could not explain the lower toxin retention in oysters according to Lindegarth et al. (2009). Therefore, the difference between mussel and oyster intoxication and depuration in this period could be related to the quantity of water filtrated by these two species: up to $2.51 \mathrm{~h}^{-1} \mathrm{~g}^{-1}$ (dry weight) in mussels (M. galloprovincialis) (Duchemin et al., 2008) and up to $4.8 \mathrm{l} \mathrm{h}^{-1} \mathrm{~g}^{-1}$ (dry weight) in oysters (C.gigas). In the same way, Troost et al., (2009) found significant differences in inhalant and exhalant current velocities and properties of the inhalant flow field (acceleration and distance of influence): at comparable body weight, inhalant current velocities were lower in C. gigas than in the other species (M. edulis) and modelled exhalant jets were higher in C. gigas (Troost et al., 2009).

\section{Conclusions}

PP2A protein phosphatase inhibition assay, as well as HPLC method, were used to analyze the toxins responsible for the contamination of mussel samples. Based on the calibration curve established with OA 
standards, it was found that shellfish samples (oysters and mussels) collected in the Lagoon of Bizerte were contaminated by DSP toxins in an investigation from April to November 2006. Therefore, the DSP contamination has posed a potent threat on public health, and it is necessary to use an accurate and convenient method, like PP2A protein phosphatase inhibition assay, to monitor DSP toxin contamination in shellfish products. The results of PP2A protein phosphatase inhibition assay of mussel and oyster extracts coincided well, but the intoxication period of mussels is longer than the intoxication period of oysters based on differences in the seawater inhalation force in these two cases. OA appeared to be reduced at a faster rate in oysters $\left(t_{1 / 2}=9\right.$ days) compared with mussels $\left(\mathrm{t}_{1 / 2}=18\right.$ days). We propose that differential rates of gut assimilation and/or biotransformation of the OA-group explain some of the observed differences in retention and toxin profiles between the bivalves, rather than differences in elimination rates. However, models related to differences in feeding rates, particle selection and behavioural response to toxic algae should be tested in future experiments to evaluate the importance of preingestive mechanisms to the differential toxin retention in these bivalves. From the industrial perspective, our results suggest that $C$. gigas may be regarded as a low-risk species for diarrhetic shellfish toxins (DST), contamination, which should be taken into consideration by regulatory authorities in charge of sampling frequencies and monitoring programs for shellfish toxins.

\section{Acknowledgements}

We are grateful for the critical comments of the referees and the help of Mrs S. Ghouti (University of Paris-Sud 11, UFR Pharmacy, the Language Department) for critical reading of the manuscript, and David Rose, Amideast, Tunis, for proof-reading. This study was supported by a fellowship to Imène Kacem from the Ministry for Higher Education and Scientific Research, Tunisia.

\section{References}

Aifeng, L., Rencheng, Y., Jun, L., Xianghai, T., Yunfeng, W., Tian, Y., \& Mingjiang, Z. (2006). Protein Phosphatase Inhibition Assay for Detection of Diarrhetic Shellfish Poison in Oyster. Chinese Journal of Analytical Chemestry, 34(3), 283-287.

Bowden, B.F. (2006). Yessotoxins-polycyclic ethers from dinoflagellates: relationships to diarrhetic shellfish toxins. Toxin Reviews, 25,137-157.

Camacho, F.G., Gallardo Rodríguez, J., Sánchez Mirón, A., Cerón García, M.C., Belarbi, E.H., Chisti, Y., \& Molina Grima, E. (2007). Biotechnological significance of toxic marine dinoflagellates. Biotechnology Advences, 25, 176-194.

Duchemin, M. B., Wessel, N., Fournier, M., \& Aufand, M. (2008). Flow cytometric measurement of clearance rate in the blue mussel mytilus edulis and the development of a new individual exposure system for aquatic immunotoxicological studies. Environmental pollution, 153 (2), 492-496.

Faust, M.A, Larsen, J., \& Moestrup, O. (1999). Potentially toxic phytoplankton. 3. Genus Prorocentrum (Dinophyceae). In: Lindsley, J.A. ed. Identification Leaflets for Plankton, Leaflet no. 184. ICES, Copenhagen pp. $1-24$.

Faust, M.A., Morton, S.L. \& Quod J.P. (1996). Further SEM study of marine dinoflagellates: the genus Ostreopsis (Dinophyceae). Journal of Phycology, 32, 1053-1065.

Kacem, I., Hajjem, B. \& Bouaicha, N. (2009). First Evidence of Okadaic Acid in Mytilus galloprovincialis Mussels, collected in Mediterranean lagoon, Tunisia. Bulletin of Environmental Contamination and toxicology, 82, 860-864. DOI 10.1007/s00128-009-9703-y

Lee, J.S., Yanagi, T., Kenma, R., \& Yasumoto, T. (1987). Fluorometric determination of diarrhetic shellfish toxins by high-performance liquid chromatography. Agriculture Biology and Chemistry, 51, 877-881.

Lindegarth, S., Torgersen, T., Lundve, B., \& Sandvik, M. (2009). Differential Retention of Okadaic Acid (OA) Group Toxins and Pectenotoxins (PTX) in the Blue Mussel, Mytilus edulis (L.), and European Flat Oyster, Ostrea edulis (L.). Journal of Shellfish Research, 28(2), 313-323.

Marasovic, I., Nincevic. Z., Pavela-Vrancic, M., \& Orhanovic, S. (1998). A survey of shellfish toxicity in the central Adriatic Sea. Journal of Marine Biology Association, U K 78, 745-754.

Sampayo, M.A., Alvito, P., Franca, S., \& Sousa, I. (1990). Dinophysis spp. toxicity and relation to accompanying species. In: Granéli, E., Sundström, B., Edler, L., Anderson, D.M.M. eds. Toxic Marine Phytoplankton. Elsevier, New York. p 215-220. 
Sournia, A. (1986). Cyanophyce'es, Dictyochophycées, Dinophycées, Raphidophycées. In: Sournia A (ed) Atlas du Phytoplancton Marin. Edition du CNRS, Paris, p 219.

Suganuma, M., Fujuki, H., Suguri, H., Yoshizawa, S., Hirota, M., Nakayasu, M., Ojika, M., Wakamatzu, K., Yamada, K., Sugimura, T. (1988). Okadaic acid: an additional non-phorbol-12-tetradecanoate-13-acetate-type tumor promoter. Proc Natl Academic Science USA, 85:1768-1771. doi:10.1073/pnas.85.6.1768

Troost, K., Stamhuis, E.J., Van Duren, L.A., \& Wolff, W.J. (2009). Feeding current characteristics of three morphologically different bivalve suspension feeders, Crassostrea gigas, Mytilus edulis and Cerastoderma edule, in relation to food competition. Marine Biology, 159: 355-372.

Tubaro, A., Florio, C., Luxich, E., Soso, S., Della Loggia, R., \& Yasumoto, T. (1996). A protein phosphatase 2A inhibition assay for a fast and sensitive assessment of Okadaic contamination in mussels. Toxicon, 34: 743-752. doi:10.1016/0041-0101(96)00027-X

Yasumoto, T., \& Murata, M. (1993). Marine toxins. Chemistry Reviews, 93: 1897-1909. doi: $10.1021 / \mathrm{cr} 00021 \mathrm{a} 011$

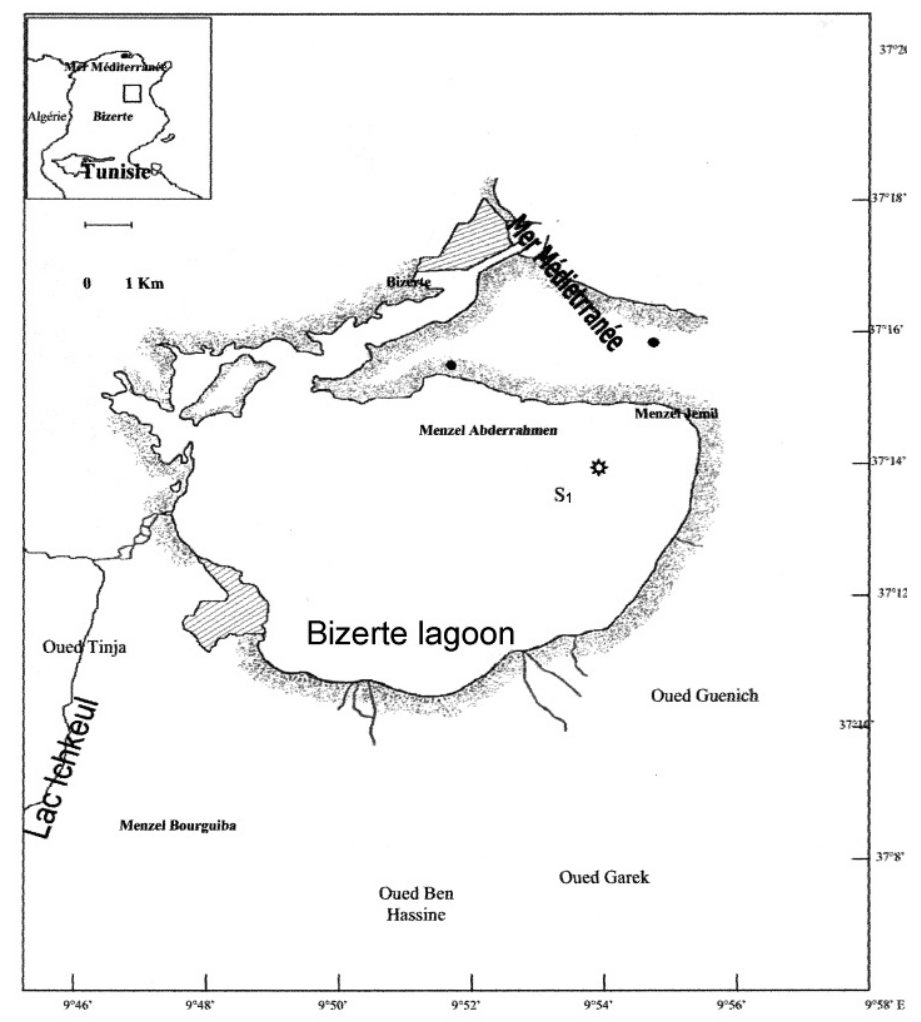

Figure 1. The study area, showing the sampling station in the Bizerte lagoon, NE of Tunisia (SE Mediterranean). S1: site of sampling 


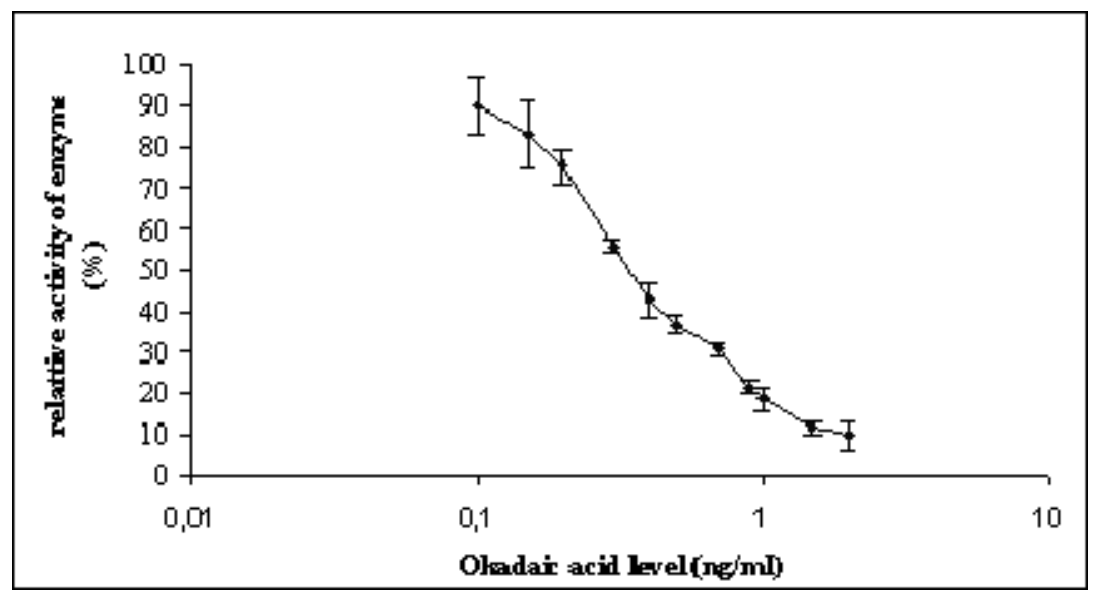

Figure 2. Standard calibration curve of relative PP2A protein phosphatase activity against concentration of okadaic acid

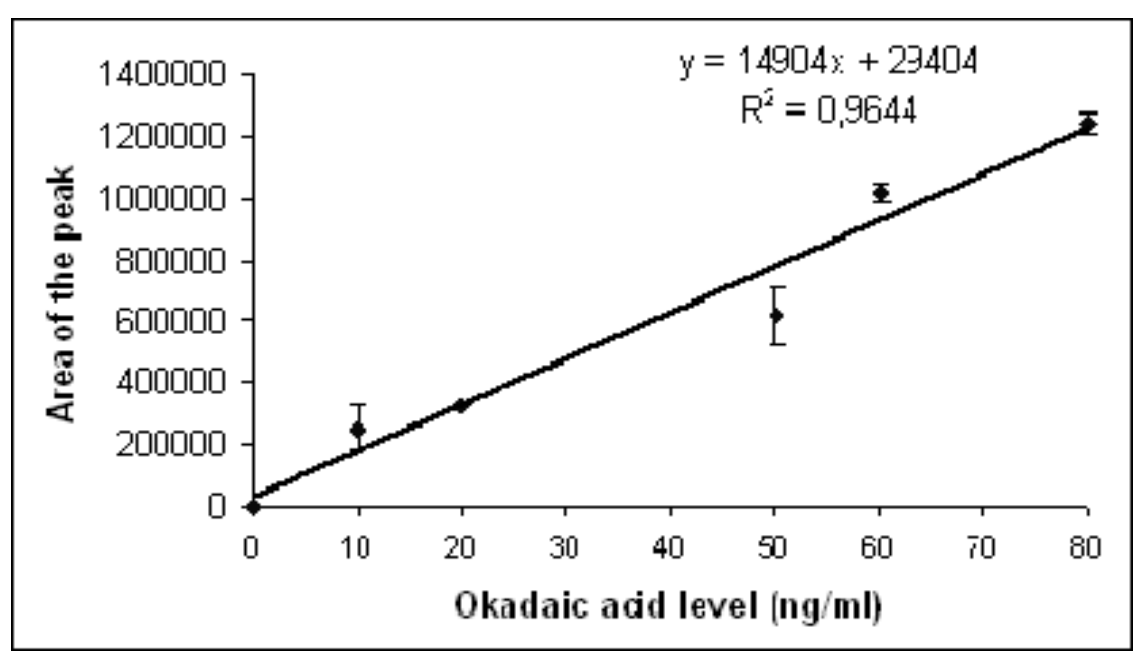

Figure 3. Standard calibration curve of okadaic acid (High Performance Liquid Chromatography assay) 


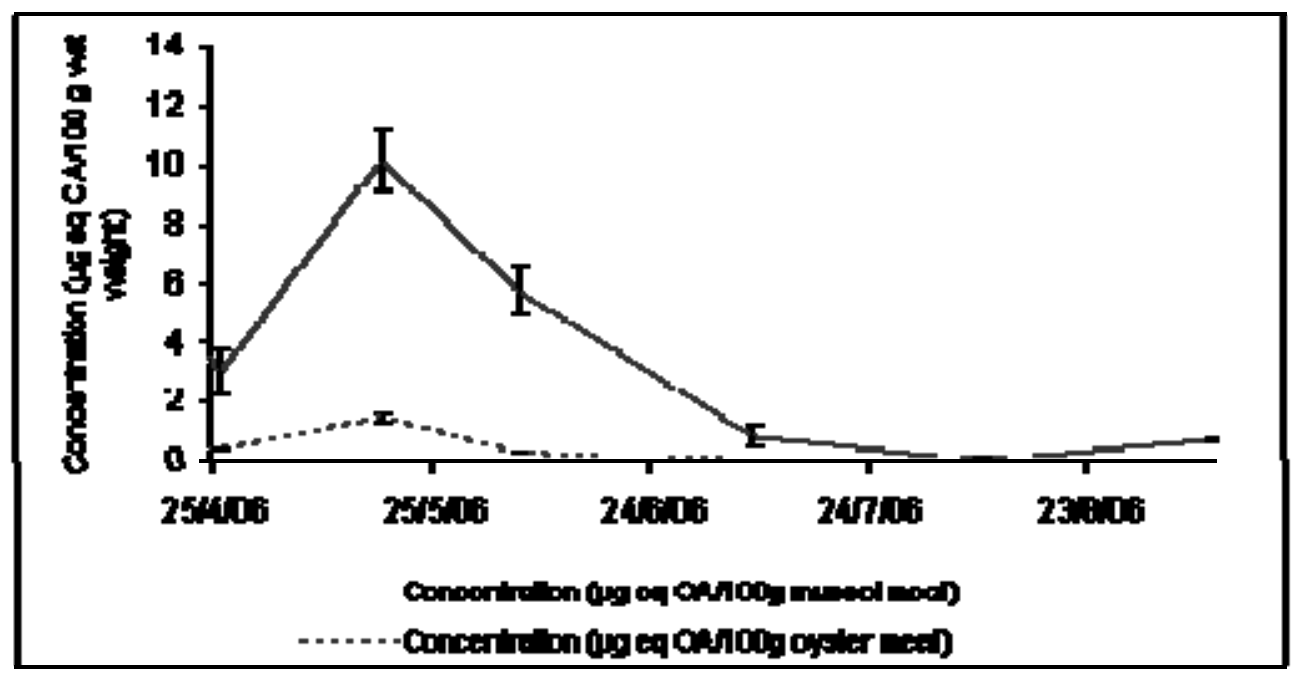

Figure 4. Presentation of monthly fluctuation of okadaic acid-like toxins contents in mussel (M. galloprovincialis) and oyster (C. gigas) samples collected in Bizerte Lagoon from April to November 2006 and determined by the $\mathrm{PP} 2 \mathrm{~A}$ assay. Each value is the mean $\pm \mathrm{SD}$ of three replicates

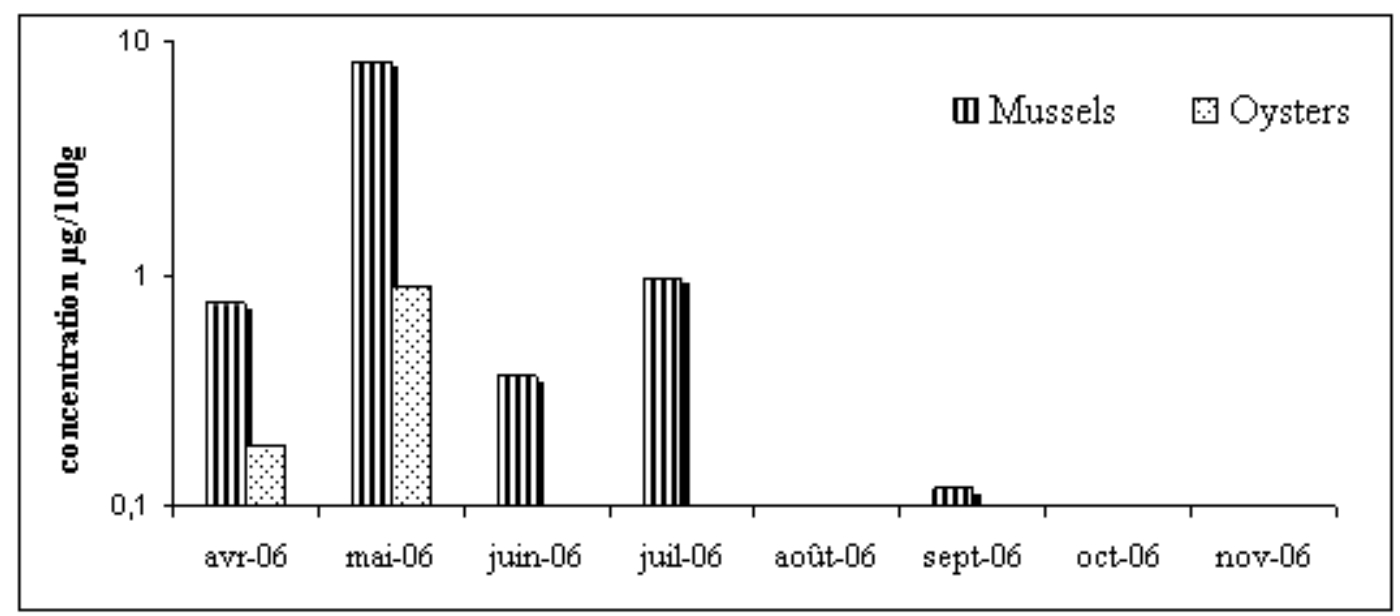

Figure 5. Presentation of monthly fluctuation of okadaic acid toxins contents in mussel (M. galloprovincialis) and oysters (Crassostrea gigas) samples collected in Bizerte Lagoon from April to November 2006 and determined by the HPLC-ADAM method. Each value is the mean $\pm \mathrm{SD}$ of three replicates 